\title{
Oil Characterization and Seeds Composition of Sicana odorifera, an Ancestral Cucurbita from Paraguay ${ }^{\dagger}$
}

\author{
Laura Mereles*(D), Eva Coronel (D), Loida Galeano and Silvia Caballero
}

check for updates

Citation: Mereles, L.; Coronel, E.; Galeano, L.; Caballero, S. Oil Characterization and Seeds Composition of Sicana odorifera, an Ancestral Cucurbita from Paraguay. Biol. Life Sci. Forum 2021, 8, 2. https://doi.org/10.3390/ blsf2021008002

Academic Editors: Loreto Muñoz and Claudia M. Haros

Published: 2 December 2021

Publisher's Note: MDPI stays neutral with regard to jurisdictional claims in published maps and institutional affiliations.

Copyright: (c) 2021 by the authors. Licensee MDPI, Basel, Switzerland. This article is an open access article distributed under the terms and conditions of the Creative Commons Attribution (CC BY) license (https:/ / creativecommons.org/licenses/by/ $4.0 /)$.
Dirección de Investigaciones, Facultad de Ciencias Químicas, Universidad Nacional de Asunción, San Lorenzo P.O. Box 1055, Paraguay; ecoronel@qui.una.py (E.C.); loida21galeano@gmail.com (L.G.); scaballero@qui.una.py (S.C.)

* Correspondence: lauramereles@qui.una.py

† Presented at the III Conference la ValSe-Food and VI Symposium Chia-Link Network, online, 15-17 November 2021.

Abstract: Sicana odorifera seeds, from an ancestral Cucurbita growing in Paraguay, possess important biowaste after fruit pulp use. However, there are reports that its infusions can reduce and cure the symptoms of viral diseases such as hepatitis, denoting its medicinal properties. The recovery of nutrients and bioactive molecules from its bio-residues has potential uses in the industrial sector with high added value as functional food ingredients. In S. odorifera species, although it is not a fruit for mass consumption, it is precisely the lack of a market for its biowaste that has limited its integral use. Based on this, the centesimal composition, oil characterization, and fatty acids profile of the kurugua seeds from two accessions (atropurpurea (black) and reddish) were studied. Kurugua seeds have been subjected to a cold extraction with a hydraulic press from dried whole seeds, and ISO and AOCS standard methods were used for analytical determinations. The major components in the centesimal composition of kurugua seeds were lipids, dietary fiber, and proteins. The oils presented iodine, saponification, and refractive indices characteristic of preferentially polyunsaturated oils. The major component in the fatty acid profile was linolenic acid, an important essential fatty acid in the diet. Although the characteristics of kurugua oil, demonstrate its potential application in the food industry as a polyunsaturated oil, source of essential fatty acids, future studies on stability and sensory analysis for food applications are suggested, with great possibilities for the food safety framework.

Keywords: biowaste; composition; Cucurbita; fatty acids; oil; Sicana odorifera

\section{Introduction}

The ancestral species of the Cucurbitaceae family are part of the cultural and food heritage of several nations. However, some members of this family, such as S. odorifera, have been losing prominence to the point of being undervalued at the regional level, despite their delicate and delicious aroma and flavor and the multiple potential applications of its pulp [1].

The seeds of these fruits are important bio-residues. There are reports that its infusions can reduce and cure the symptoms of viral diseases such as hepatitis, denoting its medicinal properties. In $S$. odorifera species, although it is not a fruit for mass consumption, it is precisely the lack of a market for its biowaste that has limited its integral use. The recovery of nutrients and bioactive molecules from the bio-residues has potential uses in the industrial sector with high added value as functional food ingredients, which can be used by the health food industry [2].

The aim of this work was to characterize the composition of the seeds of S. odorifera in its two varieties (with fruits with black skin and reddish skin), which presents an opportunity to explore the use of biowaste from their pulp. 


\section{Materials and Methods}

\subsection{Plant Material}

The fruits of Sicana odorifera collected in January 2020, from the Cordillera Department, Juan de Mena city $\left(24^{\circ} 57^{\prime} 35.8^{\prime \prime}\right.$ S, $56^{\circ} 44^{\prime} 20.0^{\prime \prime}$ W) Paraguay, are of two varieties; anthropurpurea (black) and reddish, harvested in 2020 in a mature state they did not show visible damage, and were sent to the laboratory for further analysis. The seeds were manually separated from the pulp and immediately analyzed to determine their physicochemical characteristics. For the centesimal composition, they were dried in a vacuum oven for $24 \mathrm{~h}$ at $60^{\circ} \mathrm{C}$.

\subsection{Obtaining the Oil}

The sample was weighed into a $250 \mathrm{~mL}$ Erlenmeyer flask and hexane was added maintaining the ratio $1: 5(p / v)$, this was stirred for approximately $3 \mathrm{~h}$. Then, it was filtered under vacuum and subsequently the solvent was evaporated in a rotary evaporator $\left(60^{\circ} \mathrm{C}\right)$.

\subsection{Analysis}

The proximal composition analysis was determined by official methodologies [3] moisture (method No. 934.06), ash (method No. 968.08), dietary fiber (method No. 985.29), total lipids (method No. 948.22), and total nitrogen using the conversion factor 6.25 from nitrogen to proteins (method No. 970.39). The content of total carbohydrates and soluble sugars was determined by the Clegg anthrone method. The results were expressed in $\mathrm{g} / 100 \mathrm{~g}$ on dry samples. The oil characterization parameters were measured by official AOCS methodologies (2009) [4], where the iodine index was performed by the Cd 1-25 method, the saponification index by the Cd 3-25 method and the refraction index by method Cc 7-25. The density corresponds to the magnitude that expresses the relationship between mass and volume. $1 \mathrm{~mL}$ of kurugua seed oil, black and red peel, was weighed, and later the mass-volume relationship was calculated. Kurugua seeds have been subjected to a cold extraction with a hydraulic press from dried whole seeds, and the ISO and AOCS standard methods were used for analytical determinations.

\subsection{Statistical Analysis}

The data were recorded in an Excel spreadsheet and analyzed in the statistical program Graphpad prism 5.0 (GraphPad Software Inc., San Diego, CA, USA). Student's t $(p \leq 0.05)$ was used to determine the significant differences.

\section{Results}

\subsection{Proximal Composition}

The S. odorifera seeds of the analyzed varieties have similar shapes; they are flat oval and brown in color. Unlike the seeds of the black variety, which is uniform in color over the entire surface, the seeds of the red variety have a light brown interior and a darker brown halo on the edges. These characteristics are distinctive (Figure 1). In dry seeds, the major components in the centesimal composition of kurugua seeds were lipids (greater than $34 \%$ ), dietary fiber (greater than $34 \%$ ), and proteins (greater than $17 \%$ ), as observed in Table 1. 


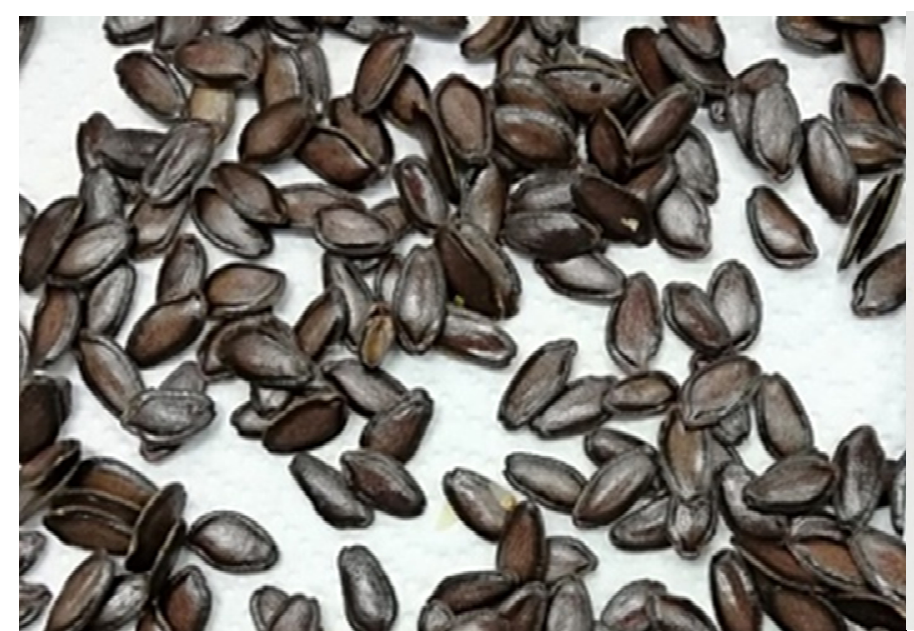

(a)

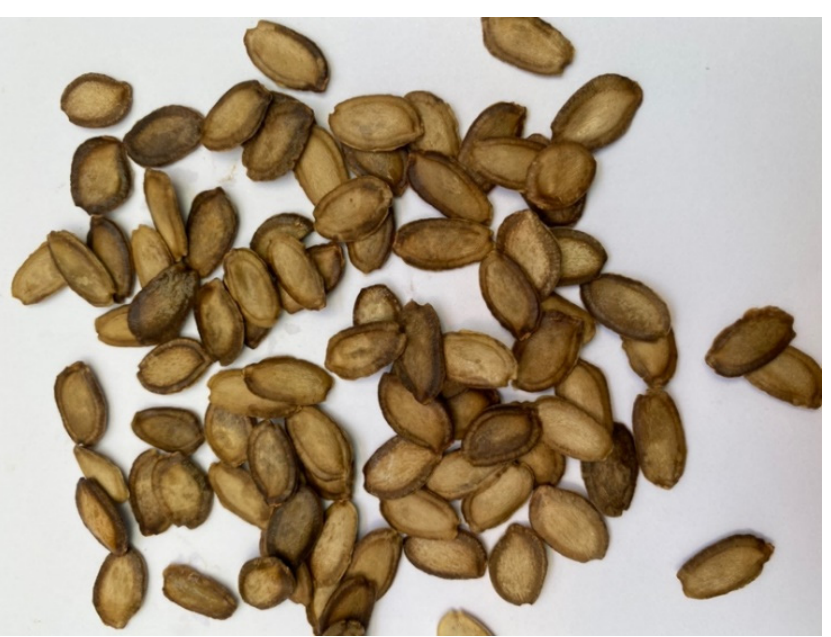

(b)

Figure 1. S. odorifera seeds from (a) black fruits and (b) reddish fruit.

Table 1. Centesimal composition and caloric value of S. odorifera kurugua seeds.

\begin{tabular}{ccc}
\hline Parameter & Black Kurugua Seeds & Red Kurugua Seeds \\
\hline Moisture $(\mathrm{g} / 100 \mathrm{~g})$ & $10.63 \pm 0.23^{\mathrm{a}}$ & $7.70 \pm 0.26^{\mathrm{b}}$ \\
Ash $(\mathrm{g} / 100 \mathrm{~g})$ & $2.48 \pm 0.14^{\mathrm{a}}$ & $2.64 \pm 0.02^{\mathrm{b}}$ \\
Total protein $(\mathrm{g} / 100 \mathrm{~g})$ & $17.40 \pm 0.81^{\mathrm{a}}$ & $18.55 \pm 0.55^{\mathrm{a}}$ \\
Total lipids & $34.50 \pm 0.28^{\mathrm{a}}$ & $36.3 \pm 0.49^{\mathrm{a}}$ \\
Total carbohydrates $(\mathrm{g} / 100 \mathrm{~g})$ & $2.78 \pm 0.06^{\mathrm{a}}$ & $3.40 \pm 0.32^{\mathrm{a}}$ \\
Dietary fiber $(\mathrm{g} / 100 \mathrm{~g})$ & $34.75 \pm 0.27^{\mathrm{a}}$ & $39.94 \pm 0.08^{\mathrm{a}}$ \\
Caloric Value $($ Kcal/100 g) & $391 \pm 2.57^{\mathrm{a}}$ & $415 \pm 4.67^{\mathrm{b}}$ \\
\hline
\end{tabular}

The values expressed on dry weight, as the average of three repetitions \pm DS. Different lowercase letters in each row indicate significant difference between the means (Student's $t, p \leq 0.05$ ).

\subsection{Characterization of the Oil and Fatty Acid Profile of the Seeds}

The Characterization of the oil from the seeds of S. odorifera are observed in the Table 2. On the other hand, the profile of the major fatty acids of the seeds oil are presented in Table 3. Eight different fatty acids were identified in the oil by GC/MS. Unsaturated fatty acids predominated in the seed oil with an average of $82.2 \%$. The dominant fatty acid was C18: 3 omega 3 linolenic acid in both varieties (32.8-38.08\%), together with C18: 2 omega 6 linoleic acid (28.62-29.52\%) and acid oleic C18: 1 omega 9 (12.77-19.09\%).

Table 2. Characterization of the oil from the seeds of S. odorifera.

\begin{tabular}{ccccc}
\hline Variety & $\begin{array}{c}\text { Iodine Value } \\
\left(\mathbf{g I} \mathbf{I}_{\mathbf{1 0 0}} \mathbf{g}\right)\end{array}$ & $\begin{array}{c}\text { Saponification Index } \\
(\mathbf{m g ~ K O H} / \mathbf{g})\end{array}$ & $\begin{array}{c}\text { Density } \\
(\mathbf{g} / \mathbf{m L}), \mathbf{2 5}^{\circ} \mathbf{C}\end{array}$ & $\begin{array}{c}\text { Refractive Index } \\
\mathbf{N D}, \mathbf{2 5}{ }^{\circ} \mathbf{C}\end{array}$ \\
\hline Black fruit seeds & $132.76 \pm 2.29^{\mathrm{a}}$ & $166.88 \pm 0.30^{\mathrm{a}}$ & $0.87 \pm 0.02^{\mathrm{a}}$ & $1.479 \pm 0.33^{\mathrm{a}}$ \\
Reddish fruit seeds & $130.58 \pm 2.00^{\mathrm{a}}$ & $182.42 \pm 0.00^{\mathrm{b}}$ & $1.09 \pm 0.00^{\mathrm{b}}$ & $1.478 \pm 0.00^{\mathrm{a}}$ \\
\hline
\end{tabular}

Values are the mean \pm SD of three determinations on oil seeds. Different lowercase letters in each column indicate significant difference between the means (Student's $t, p \leq 0.05$ ). 
Table 3. Fatty acids profile of $S$. odorifera seeds oil.

\begin{tabular}{|c|c|c|c|}
\hline \multicolumn{2}{|c|}{ Fatty Acids } & \multirow{2}{*}{$\begin{array}{c}\text { Reddish Fruit Seeds (g/100 g Oil) } \\
32.80 \pm 0.13^{\mathrm{a}}\end{array}$} & \multirow{2}{*}{$\begin{array}{c}\text { Black Fruit Seeds (g/100 g Oil) } \\
38.08 \pm 0.06^{\mathrm{b}}\end{array}$} \\
\hline Polyunsaturated & Linolenic $(\omega-3)$ & & \\
\hline & Linoleic $(\omega-6)$ & $28.62 \pm 0.17^{\mathrm{a}}$ & $29.51 \pm 0.21^{b}$ \\
\hline & 8.11 octadecadienoic Acid. & $1.26 \pm 0.03^{\mathrm{a}}$ & $1.18 \pm 0.01^{\mathrm{a}}$ \\
\hline \multirow{2}{*}{ Monounsaturated } & Oleic $(\omega-9)$ & $19.39 \pm 0.11^{\mathrm{a}}$ & $13.16 \pm 0.55^{\mathrm{a}}$ \\
\hline & Palmitoleic $(\omega-7)$ & $0.09 \pm 0.01^{\mathrm{a}}$ & $0.06 \pm 0.01^{\mathrm{a}}$ \\
\hline TOTAL & & 82.16 & 81.99 \\
\hline \multirow[t]{3}{*}{ Saturated } & Miristic (14:00) & $0.12 \pm 0.02^{a}$ & $0.12 \pm 0.01^{\mathrm{a}}$ \\
\hline & Palmitic (16:00) & $10.98 \pm 0.17^{\mathrm{a}}$ & $10.93 \pm 0.08^{a}$ \\
\hline & Estearic (18:00) & $6.74 \pm 0.07^{\mathrm{a}}$ & $6.96 \pm 0.17^{\mathrm{a}}$ \\
\hline TOTAL & & 17.84 & 18.01 \\
\hline
\end{tabular}

Values are the mean $\pm \mathrm{SD}$ of three determinations on oil seeds.

\section{Discussion}

At a moisture level below $11 \%$, the total lipid content in S. odorifera seeds observed is higher than that reported in seeds of fruits of the same family of Cucurbitaceae such as squash Cucurbita maxima (30.66 g/100 g) [5].

The oils presented iodine, saponification, and refractive indices characteristic of preferentially polyunsaturated oils. The iodine value indicates the degree of unsaturation of the fatty acids in an oil. According to these results, kurugua seeds would have the presence of unsaturated fatty acids, and classifies it as a "semi-drying oil". Our results for black and red kurugua seeds were similar to Cucurbita moschata Duch "zucchini or long-necked squash" (132.7 $\left.\mathrm{gI}_{2} / 100 \mathrm{~g}\right)$. However, the saponification index of the analyzed kurugua seeds (166.88 \pm 0.30 and $182.42 \pm 0.01 \mathrm{mg} \mathrm{KOH} / \mathrm{g}$, in black and red Sicana sp. seed oils, respectively), was higher than that reported for C. moschata $(122.90 \mathrm{mg} \mathrm{KOH} / \mathrm{g}$ ) [6].

The fatty acid composition of the seeds depends on their genetic characteristics, but the latitude and climatic conditions of cultivation also have a strong influence on fatty acid biosynthesis. The observed values of the content of these fatty acids are lower than those reported for chia seeds, recognized as a source of essential fatty acids [7]. Although the oil from kurugua seeds has not been previously characterized in the light of our knowledge, the seeds of S. odorifera that grow in Paraguay can provide essential fatty acids such as omega 3 and omega 6 . These results demonstrate their nutritional qualities, with potential for use as a food ingredient in healthy prepared food preparations.

\section{Conclusions}

S. odorifera seeds have a lipid content with good nutritional characteristics, preferably polyunsaturated fatty acids, were omega 3 linolenic acid was the mayority. Future studies on stability and sensory analysis for food applications are suggested, with potential aplications, on food safety framework.

Institutional Review Board Statement: Not applicable.

Informed Consent Statement: Not applicable.

Data Availability Statement: Not applicable.

Acknowledgments: This work was supported by grant Ia ValSe-Food-CYTED (119RT0567), "Kurugua poty" Foundation and Canindeyú Department Government. Bioq. Allison Alegre and the student Elaine Ibarrola, for their collaboration in the analysis of the fatty acid profile. 


\section{References}

1. De Paula Filho, G.X.; Barreira, T.F.; Pinheiro, S.S.; de Morais Cardoso, L.; Duarte Martino, H.S.; Pinheiro-Sant'Ana, H.M. 'Melão croá' (Sicana sphaerica Vell.) and 'maracujina' (Sicana odorifera Naud.): Chemical composition, carotenoids, vitamins and minerals in native fruits from the Brazilian Atlantic forest. Fruits 2015, 70, 341-349. [CrossRef]

2. Albuquerque, B.R.; Dias, M.I.; Pereira, C.; Petrović, J.; Soković, M.; Calhelha, R.C.; Oliveira, M.B.P.P.; Ferreira, I.C.F.R.; Barros, L. Valorization of Sicana odorifera (Vell.) Naudin Epicarp as a Source of Bioactive Compounds: Chemical Characterization and Evaluation of Its Bioactive Properties. Foods 2021, 10, 700. [CrossRef] [PubMed]

3. Horwitz, W. Official Methods of Analysis of the Association of Official Analytical Chemists, 17th ed.; AOAC: Gaithersburg, MA, USA, 2000.

4. Firestone, D. (Ed.) Official Methods and Recommended Practices of the American Oil Chemist's Society AOCS, 6th ed.; AOCS: Urbana, IL, USA, 2009.

5. Shahangir, A.H. Nutritional and Lipid Composition Analysis of Pumpkin Seed (Cucurbita maxima Linn.). J. Nutr. Food Sci. 2015, 5, 374. [CrossRef]

6. Ortiz Grisales, S.; Pasos López, S.; Abadía Rivas, X.; Valdés Restrepo, M.P.; Vallejo Cabrera, F. Extracción y caracterización de aceite de semillas de zapallo. Acta Agronómica 2009, 58, 145-151. Available online: https://www.redalyc.org/articulo.oa?id=1699 16219005 (accessed on 15 September 2021).

7. Hernández-Pérez, T.; Valverde, M.E.; Orona-Tamayo, D.; Paredes-Lopez, O. Chia (Salvia hispanica): Nutraceutical Properties and Therapeutic Applications. Proceedings 2020, 53, 17. [CrossRef] 